\title{
The Implementation of Genre Based Approach to Teaching Narrative Listening
}

\author{
Setyo Prasiyanto Cahyono \\ English Department, Faculty of Humanities \\ Universitas Dian Nuswantoro \\ setyo.cahyono@dsn.dinus.ac.id
}

\begin{abstract}
This research examines the implementation of Genre Based Approach in teaching narrative listening as an approach to motivate the students to learn listening. The design of this research used a case study involving a lecturer and 32 of the third semester students who took Advanced Listening at English Department Faculty of Humanities, Universitas Dian Nuswantoro Semarang. Meanwhile, the data were gained from the students' narrative writings and listening answer sheets as the result of the teaching and learning process and took 5 data purposively as the samples of this research. The findings depict that lecturer was successfully applied GBA in the process of teaching and learning narrative listening. Furthermore, it also shows that the implementation of GBA enhances students' ability in listening comprehension and it can be indicated through students' listening answer sheets and writings. They can follow the schematic structure and linguistic features very well and apply them in their writings.
\end{abstract}

Keywords-advance listening, GBA, linguistic features, narrative listening, schematic structure

\section{INTRODUCTION}

Teaching listening comprehension for English Foreign Language learners is one of the most vital and difficult task for listening one of English skills requires much attention and concentration in learning it. Listening to foreign language speakers through authentic materials might cause a lot of problems for language learners [1]. It does not mean to say that reading comprehension and writing skills are less important, but listening is the skill which is used as a gate to speaking. If someone is able to listen successfully, he will speak very well. However, for most students, listening compared to other English skills is the most difficult subject the students learned because it requires a lot of effort such as accuracy in listening the material given, concentration, vocabulary understanding, recognizing main points, making prediction and guessing unknown words or phrases. Many students fail to do so because they have difficulties in catching the idea of the speakers' talk since the speakers speak too fast. Otherwise, these problems become the researcher awareness to be more creative and assertive in conducting teaching and learning process of listening.

In teaching listening, the researcher always tries to seek the best way to improve his students' ability in listening. In this case, the researcher employs an approach which is always used in teaching writing namely Genre Based Approach, herewith, GBA. Genre based approach has been widely used as one of the approaches to teaching writing. In teaching writing, mostly lecturers implement it as its approach since it provides stages of learning cycles. GBA has been introduced by many experts. [2], one of the experts, argues that "Genre is a technical term for a particular instance of a text type." In addition, [3] defines, "Genre is a term for grouping texts together, representing how writers typically use language to respond to recurring situations." Moreover, as an English lecturer, the researcher tries to develop this approach into a wider context of teaching English skills in term of Listening.

Narrative, one of the genres, is chosen because it provides a story which is used to amuse and entertain the readers or listeners and to deal with problematic events which lead to a crisis and its resolution [4]. In teaching advanced listening, the researcher, also acts as the lecturer, gave not only audio but also audio visual such as movie. Indeed, the audio and movies used here are related to narrative ones. Otherwise, during the teaching and learning process, the students do not only learn listening but also writing skill at the same time as the result of listening given.

Based on the reasons stated in the previous paragraph, the researcher, through this research, wants to develop his teaching methodology in order to his students understand more about listening they learned. In so doing, this research is aimed to answer the questions as follows: 1) how is the implementation of GBA in teaching Advanced Listening? and 2) how does the implementation of GBA affects students' development in Advanced Listening?

\section{THEORETICAL REVIEW}

\section{A. Listening}

Listening comprehension is one of the most important and difficult tasks for many English language learners as well as teachers/lecturers because there is no rules and grammar needed in learning or teaching it. When people listen to others such as listening to a lecture, a news broadcast, or a joke, or are engaging to conversation, it means that they are listening to a stretch of discourse [5]. In 
fact, listening is the most frequently used language skill in everyday life since. According to [6] English listening is widely acknowledge as a major challenge for EFL learners, and it has been reported as one of the most difficult skills in comparison with reading, speaking and writing, especially for EFL learners with relatively lower English proficiency [7].

Over the years, many researchers have been developing listening strategies by creating some methods or strategies in teaching listening. The levels of learners' listening are different from each other because there are some crucial factors affect listening. These factors should be emphasized on the significance of listening, the study of listening teaching theory and use of the most advanced listening teaching method [8]. In so doing, the listening lesson that one encounters in good ELT practice today has rather different structure, which includes some or most elements as shown in the table below:

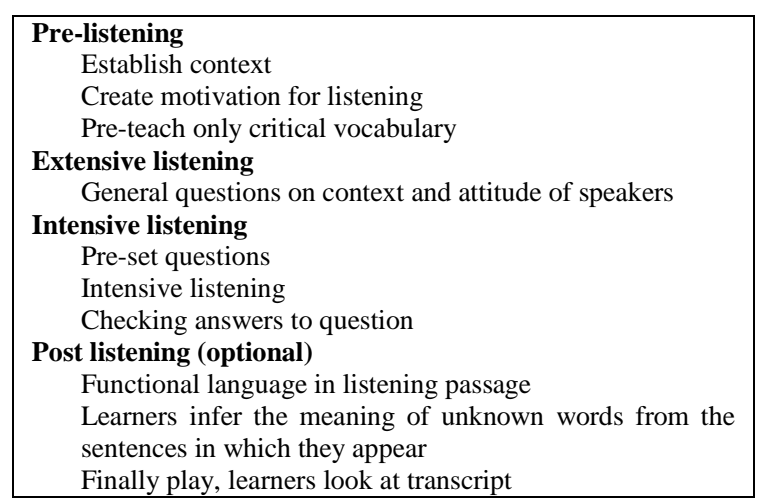

Fig 1. Current Format for a Listening Lesson [9]

It can be said that based on the table 1 above in teaching or learning listening, it should be started by establishing context of the listening material discussed. Besides, creating learners' motivation is the lecturer's role so his students can accept the listening material very well.

\section{B. Genre}

As it known that genre based approach, hereafter GBA, has been used in Indonesia since the implementation of the 2006 curriculum. It has been widely used for teaching English skills especially writing. As cited in [9] genre is defined in term of social purpose [10]. Eggin in [11] states that genre analysis is a first step towards making explicit the cultural and social basis of language in use. In addition, genre as cited in [12] is also described by Martin as 'as stage, goal-oriented, purposeful activity in which speakers engage as members of our culture. Meanwhile, in Indonesia, the application of Genre based approach is conducted in two cycles; they are spoken and written cycles. In this case, the teaching of advanced listening is adapted by the genre based approach where writing as the result of the study.

In so doing, the use of two cycles mentioned before enable students to produce their own texts either spoken or written texts at the end of teaching and learning process.
Moreover, the students do not only learn listening but also writing at the same time.

\section{Narrative Listening}

Narrative listening, a term the researcher chose, is a combination of listening and narrative. It means that in giving the listening material to his students, the researcher develops his own authentic material in term of text book and the use of media such as movie. There are various researches which have proved that listening comprehension can be improved by the addition of images [13]. In other words, by using images such as movies can motivate the students in learning listening and also encourage them to be more enthusiastic. Therefore, movie is a motivating media since it provides variety topics and it is also presented with both audio and visual.

In narrative listening, the students are encouraged to produce two products of texts whether it is spoken or written texts. Referring to the GBA cycles explained before, the result of teaching and learning process should be measurable and observable because at the end of both cycles students must be able to produce their own texts either spoken or written texts as the product of the teaching and learning process. In other words, at the end of spoken cycle students are expected to be able to produce monologue in the same genre they are learning at that time. Similarly, in written cycle, at the end, the student must produce written text of a similar genre they discus on that day. For example: if they discuss narrative listening genre by listening to the audio or visual audio (movies), at the end of the teaching and learning process students must be able to write or tell a narrative story.

\section{METHOD}

\section{A. Participants}

This research was related to the analysis of teaching advanced listening through the implementation of GenreBased Approach. Based on the statements of the problem stated in the background, this paper observed how the lecturer performed the process of teaching and learning and how the implementation of GBA affects students' development in Advanced Listening. The participants of this research were the third semester students of English Department; Faculty of Humanities Universitas Dian Nuswantoro Semarang who took Advanced Listening class comprises 30 students consisting of 13 males and 17 females.

\section{B. Data Collection and Analysis}

The research design of this study was qualitative approach comprising the data collection and qualitative data analysis. Meanwhile, the techniques of data collection used in this research were triangulation methods by doing classroom observation, students' interviews and 
documentation of the students' texts. In observation phase, the researcher came to the advanced listening class and observed the implementation of genre based approach in teaching advanced listening. The implementation of GBA was conducted during 3 meetings. In conducting the teaching advanced listening, the lecturer gave a warm up by inviting some students to give presentation orally about the topic they discussed on that day. The students were given 3 minutes to present the topic before they engaged to the listening material. Moreover, during the students' presentation, other students who did not have a chance to give presentation were asked to deliver questions to the presenters to get their understanding about the topic the students presented. During the teaching and learning advanced listening process, the lecturer used listening text books and movies with a similar topic discussed namely narrative by applying learning cycles proposed by Callaghan and Rothery (1998) as cited in [14]. In addition, an individual interview was conducted with a lecturer and 12 students from different level of ability purposively. This interview was to investigate the activities done during the teaching and learning process by employing genre base approach. In present research, the participants, at the end of the class, were handed a narrative texts as a result of their narrative listening learning. Then, using Systemic Functional Linguistics analysis, the students' texts were analyzed in term of schematic structure and language features used to reveal the students' development during the listening process depicted in their writings. The figure 2 below depicts the learning cycles which was implemented in the advanced listening by the lecturer which was proposed by [12] as adapted from Callaghan and Rothery (1988).

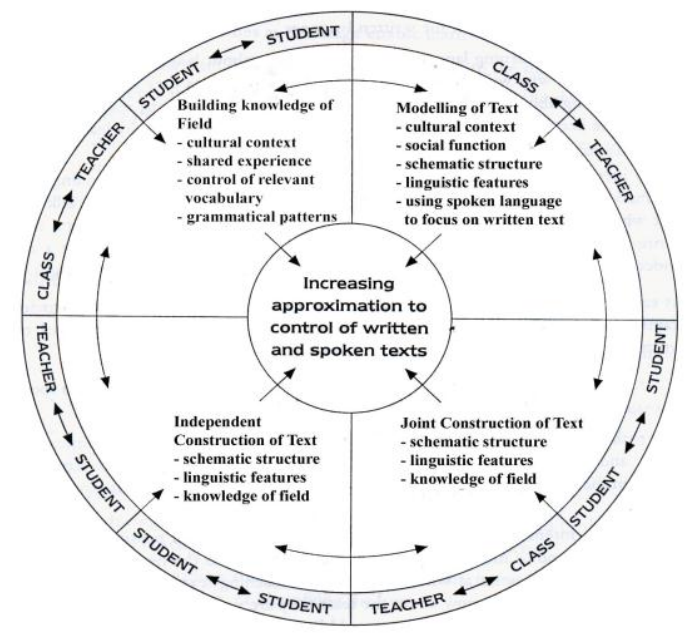

Fig 2. Teaching Learning Cycles

\section{RESULTS AND DISCUSSION}

\section{A. The Implementation of Genre Based Approach}

Based on the observation the researcher did in the advance listening classroom, it can be seen that the lecturer have implemented the genre based approach in teaching advance listening successfully. It is proved by the steps the lecturer did in teaching advanced listening. The steps here refer to the learning cycles he implements in advanced listening class covers building knowledge of field, modeling of text, joint construction and the last step is independent construction. The brief explanation is described as follows:

\section{Phase 1 : Building Knowledge of Field}

Before starting the listening material, in this phase, the lecturer invites some students to present a narrative story based in the topic they discussed on that day. Each student gives 3 minutes to present in front of the class and let other students ask him/her questions based on the story he/she delivers. Afterward, the lecturer, then, explains briefly about narrative text including the social function, schematic structure and linguistics features of narrative. This building knowledge of field is extremely important to the students because it enables the students gain the knowledge of the cultural and social context of the topic they discussed. It is also important that the lecturer explains the common vocabulary used in narrative so during the listening or watching movie the students can understand these common words. As a result, the students gain enough background knowledge of the topic they wanted to discuss.

\section{Phase 2 : Modeling of Text}

This phase of modeling of text enable students to understand detail of the social function, schematic structure and linguistics features of narrative listening they listen or watch. Besides that, the lecturer also gives examples of narrative texts by providing narrative texts as shown in the figures below:

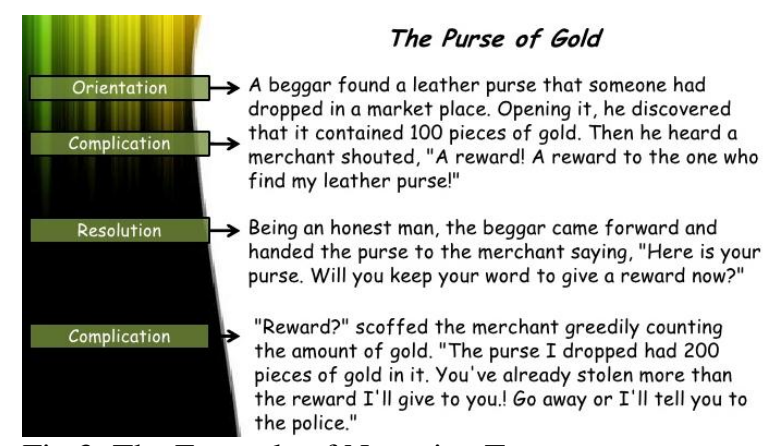

Fig 3. The Example of Narrative Text

Furthermore, at this phase, lecturer also acts as a facilitator in order to guide his students if they meet difficulties in understanding and catching ideas or vocabularies and phrases produced by the characters from the audio they listen or a movie they watch. In this stage, the lecturer must give as many as examples of narrative texts so his students can fully understand about the narrative schematic structure and linguistics features.

\section{Phase 3 : Joint Construction}

During this stage, in joint construction, the lecturer again plays a movie entitled "Ever After". The lecturer, together with his students, analyzes the movie they watch by pausing 
in each part of the schematic structure and focus on the linguistic features used by the characters. Since the duration of the movie is too long (about 100 minutes) so the movie is cut based on each of the schematic structures of narrative text namely orientation $\wedge$ complication and evaluation $\wedge$ resolution $\wedge^{\wedge}$ coda. Through this method, the students can understand how to segment the schematic structure of the movie as well finding its linguistic features such as specific participants, the use of processes (material, behavioral, verbal, relational and metal processes), temporal conjunctions and circumstances as well as simple past tense as drawn in the figure below:

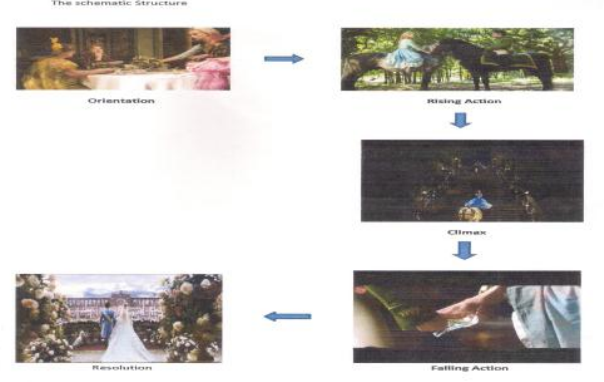

Fig 4. The Schematic structures of Narrative Text of "Ever After" Movie

\section{Phase 4 : Independent Construction}

Before engaging to the last phase of the learning cycles called independent construction, the lecturer evaluates and reviews the students' knowledge and understanding about the materials given from phase to phase. Then, he gives the students assignment individually to watch a movie entitled "Cinderella" and ask them to rewrite a text with their own words by analyzing the schematic structures and linguistics features of the movie they watch. The students' writings are the result of their listening understanding about narrative listening because they also have to find vocabularies and specific participants related to narrative text and also answer some questions given by the lecturers related to the movie "Cinderella". In doing the assignment, the students are asked to capture each part of the schematic structure of the movie and describe each frame with their own creation in a simple way.

\section{B. Students' Narrative Listening and Writing Development}

At the end of the learning cycles described above, the students are asked to hand in their assignment in form of a text and description of the questions given by their lecturer. There are ten questions that students must answer. The students are requested to listen and watch the movie of Cinderella. The examples of this phase can be seen in the figures below:

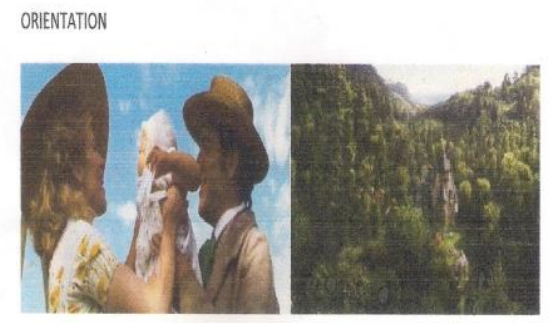

Once upon a time there was a girl called Ella. She saw the world not always as it was, but as perhaps it could be, with just little bit of magic. To her father and mother, she was a princess, she was the ruller of her own litle kingdom. Borders were the house and meadow on the forest's edge ehere her people had lived for generations. With Mr.goose and all theeir animal family. Her father was a merchant who went abroad and brought twbute back from all of Ella's subject lands.

Fig 5. Orientation of the 'Cinderella' Movie

It can be seen in the figure above that the students captured a scene of the movie "Cinderella" and classified it into orientation. In capturing this scene, it is found that the student aware the function of orientation in a movie. The figure above reveals the use of temporal conjunction begins with "Once upon a time". It is a proved that this part of scene is orientation because one of the characteristic narrative texts is started by temporal conjunction. Besides that, the use of specific participant is also another feature of orientation stated by "a girl called Ella".

The example below is the scene of complication of the movie they watch.

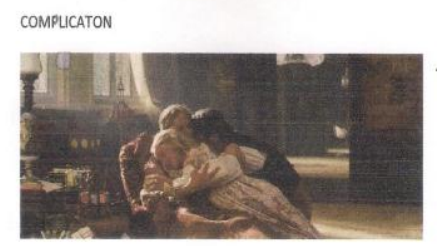

She has a happy family, but sorrow can come to any kingdom, no matter how happy. Her mother passed away because of ill, but she and her father continued to live. Time passed, and pain turned to memory in her heart. Ella stayed the same, she remembered her promise to her mother, have courage and be kind.

Fig 6. Complication of the 'Cinderella' Movie

Based on the figure above, the scene the student captured is segmented into complication. Complication tells the beginning of the problems which lead to the crisis or the main participants [10]. It can be seen that the characters are hugging each other showing that they face a problem. This complication of this scene is identified by the linguistics features such as the mental process of happy, sorrow. Besides that, it is also explained that the sorrow they faced is that Ella's mother passed away and it makes her family sad. Another example of complication arises in the movie is presented in the figure below. 


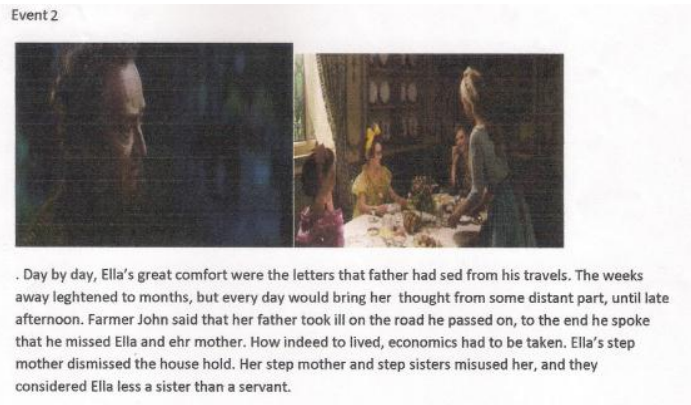

Fig 7. Event of the 'Cinderella' Movie

In this figure, the student presents another complication described in the movie. The students described in his writing that Ella is very sad because her step mother and sisters treat her like a servant at her own house after her father's dead. In addition, the student creates his writing beautifully and develops his writing with his own words and ideas based on the scene he captured.

By listening through the utterances produced by the characters, the students can develop his/her ability in listening very well. It is also described by the students' analysis as illustrated in the figure below. Here the student provides the other part of the schematic structure of the movie they watch specifically resolution.

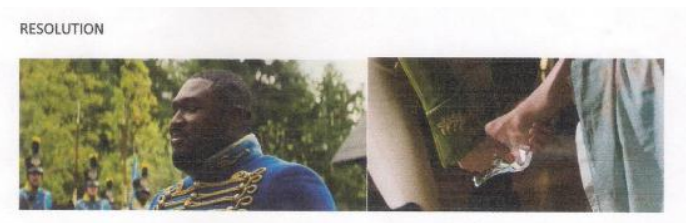

Finally the capten arrive in Ella's house, first they try the shoe to Anastasia and Driella. But no one fit, then the captain go but. He hear someone singing above there, he asked who is that. But the step mother didn't answer, suddenly the king appear, he pretend to be soldier to find his girl. They go to the attic and find Cinderella was there, and the king try the shoe to her. It's fit, her mother was

shocked. She couldn't live in the kingdom anymore.

Fig 8. Resolution of the 'Cinderella' Movie

Resolution shows how the conflicts are solved and it is indicated in the scene the student captured that finally Cinderella finds her soul mate. Here, the student develops his writing through listening and understanding the storyline of the movie.

The last part of the schematic structure the student produced is coda. It can be seen in the picture drawn below:

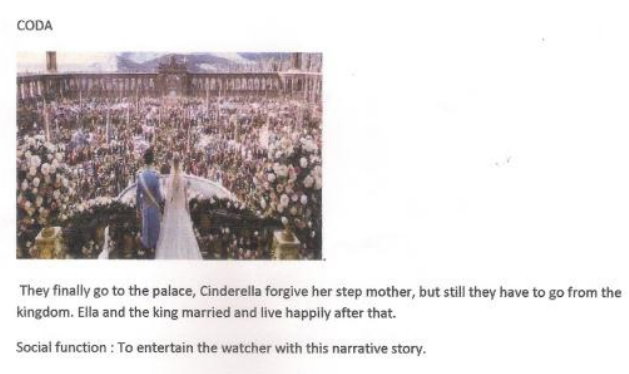

Fig 9. Coda of the 'Cinderella' Movie
It is clearly stated in the figure above that the student segments this part of the movie scene into coda because it tells the moral value of the movie and what can be learnt from the movie.

In the meantime, the students also answer some questions given by their lecturer. One of the questions along its answer can be seen in the figure below:

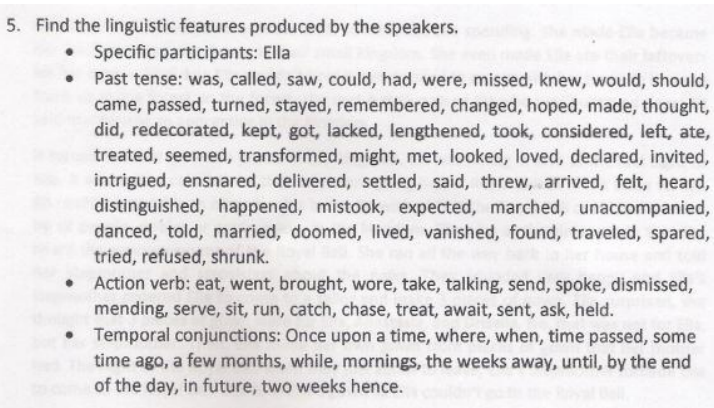

Fig 10. Linguistic Features of 'Cinderella' Movie

The above figure shows the question about the linguistic features of the movie Cinderella. As it is explained in the figure above, the student can draws the answer very well for example: the specific participant of the movie is Cinderella as the main character and also the student can represent other linguistic features such as the use of simple past tense, action verbs and conjunction.

\section{Interview}

Based on the interview data, they indicate that the lecturer has a very good comprehension of genre based approach. It is shown in they how he implements the GBA in teaching advanced listening. By applying this approach, the lecturer is able to lead the students as their facilitator in developing and understanding the narrative audio visual they learned. Furthermore, in teaching advanced listening through genre based approach, the lecturer used scaffolding approach to ensure that his students get enough skill in listening and writings a narrative text as well as lead to their development and ability in using the narrative genre. For the students, most of them said that the implementation of genre based in advanced listening class helps them to understand the listening material easily because GBA is introduced stage by stage. In addition, at the end of advanced listening, they can produce better texts as the product of the advance listening.

\section{CONCLUSION}

According to the process of learning cycles described in the result and discussion, it can be assumed that the lecturer has indeed successfully implemented genre based approach in his teaching advanced listening. Referring to the interview, the lecturer states that genre based approach is one of the best way to teaching English skills and one of them is listening skill. Arguably, genre based approach is appropriately used in teaching writing. However, the curriculum applied in English Department of Faculty of 
Humanities Universitas Dian Nuswantoro is using genre based where all four English skills; writing, speaking, reading and listening applied this approach. In doing so, the lecturers of English skills need to improve and develop their creativity in order to improve his students' ability in learning English skills specifically advanced listening. Through the application of genre based approach in advanced listening, it makes the students learn at least two English skills at the same time whether its speaking or writing.

\section{REFERENCES}

[1] Sadeghi, B., Hassani, M.T., and Noory, H. 2014. The Effect of Teaching Different Genres of Listening Comprehension Performance of Iranian EFL Students. Journal of Language Teaching and Research, 5(3), 517-523.

[2] Christie, F. \& Derewianka, B.(2008). School Discourse. New York: Continuum.

[3] Hyland, K. 2015. Genre, dicipline and identity. Journal of English for Academic Purposes. (xxx)1-12

[4] Gerot, L and Wignell, P. 1992. Making Sense of Functional Grammar. Australia: Gerd Stabler.

[5] Celce-Murcia, M and Olshtain, E. 2000. Discourse and Context in Language Teaching: a Guide for Language Teacher: Cambridge University Press.

[6] Dong, J. 2016. A dynamic systems theory approach to development of listening strategy use and listening performance. System Journal 63, 149-165.

[7] Bacon, S.M. 1989. Listening for Real om the Foreign Language Annals. 22(6), 543-550
[8] Gilakjani and Ahmadi. (2011). A Study of Factors Effecting EFL Learners' English Listening Comprehension and the Strategies for Improvement. Journal of Language Teaching and Research, Vol.2, No.5, pp.977-988.

[9] Pribady, I. 2012. The Implementation of Genre Based Approach to Teaching Narrative Writing. Proceeding of the 39th International Systemic Functional Linguistics Congress. 57-62.

[10] Cope, B., and Kalantziz, M. (1993). The Power if Literacy and the Literacy of Power. In B. Cope, B., and M. Kalantzis (Eds.), The Power of Literacy. A genre approach to teaching writing. London: The Falmer Press.

[11] Arancon, P. R. 2013. The Use of SFL Genre Theory for the Analyss of Students' Writing Skills in ESP. Volumen Monografico Journal. $245-$ 262.

[12] Paltridge, B. 2001. Genre in the Language Learning Classroom. Michigan, University of Michigan Press.

[13] Safranj, J. 2015. Advancing Listening Comprehension Through Movies. Science Direct Journal, 191(1), 169-173.

[14] Hammond.et.al. 1992. English for Specific Purposes: a Handbook for Teachers of Adult Literacy. National Centre for English Language: Sydney

[15] Eggins, S. 2004. An Introduction to Systemic Functional Linguistics (2nd Edition). London: Continuum.

[16] Farrel, T.S., and Mallard. 2006. The Use of Reception Strategies by Leaners of French as a Foregign Language. Modern Language Journal. 90(3), 338-352

[17] Field, J. 2008. Listening in Language Classroom. UK: Cambridge University Press.

[18] Renandya, W.A and Farrel, T.S. 2010. Teacher, the Tape is too Fast!' Extensive Listening in Elt. ELT Journal, 65(1), 52-59. 